\title{
THE ROLE OF SCHEMAS IN UNDERSTANDING PLACES Çağnı İMAMOĞLU
}

Received: 20.07.2009

Keywords: place; schema; place experience; place patterns; place identity; place perception; meaning; places for older adults.

1. The present paper, in part, is based on a doctoral study conducted at University of Wisconsin-Milwaukee. I express my thanks to Professor Jerry Weisman for his guidance, to the Fulbright Research Commission, Turkish Science and Research Council, and the Graduate School of University of Wisconsin-Milwaukee for providing partial financial support.
Walking into an unfamiliar building, we quickly know, for example, not only that it is a restaurant, but also what kind of a restaurant it is, what kind of people we are likely to find there and how they are likely to and 'supposed' to act (1). We are able to differentiate between customers and employees, have an idea about the location of the restrooms, the kind of food served and even the cost of eating there - without talking to anyone and in seconds! Often we can answer many of these questions even before entering the building (Cherulnik, 1991). Although we practice this "guessing game" all the time, because it comes to us so naturally, we do not even notice what we are achieving. We are able to achieve this by virtue of our mental representations called schemas.

In this paper, first, I consider the concept of place, and argue that experiences of places are mostly consensual, and that we can learn about these experiences by exploring our schemas about places. Then I review related literature on place schemas, and provide an example from the literature regarding older adults, demonstrating the value of the concept of place schema. In the second part of the paper, I propose a model to conceptualize the emergence and evolution of place identities and related place schemas; finally, I refer to some supportive evidence from my own research involving assisted living facilities, homes and nursing homes for older adults.

Environment-behaviour studies (EBS) examine the interaction of people with their surroundings. Much of EBS research has tried to 'objectively' (empirically) study parts of this interaction, hoping that in the end it would all add up to a meaningful whole. Other research that has adopted a phenomenological view has argued that most social situations can only be studied "subjectively" (interpretively), addressing the unique environmental experiences of the individual. A middle way may just be what EBS research needs, and this we can perhaps find in the concept of consensual environments, such as places (Lynch, 1960; Lee, 1970; Lawton, 
1980; Stokols and Shumaker, 1981; Groat, 1984; Weisman, Chaudhury and Moore, 2000; Weisman and Moore, 2003). A wide range of research indicates that most people have at least a partially shared understanding of their environments; it is as if they have reached a 'consensus' on features and properties of their environments, ranging from spatial relations and 'social imageability' (e.g., Lynch, 1960; Lee, 1970; also see Stokols and Shumaker, 1981) to 'rules' of place (e.g., Canter, 1985) to facilitate co-action in groups. This inter-subjective "agreement" (e.g., Lynch, 1960) may be a topic of research that is an essential part of EBS.

Thus, the concept of place is consensual (Stokols and Shumaker, 1981) - almost all people agree on the existence of places and the meanings they carry, and some seem to think places may even have 'personalities' (e.g., Geboy, 2001). However, to this day, much of EBS research has viewed environment as a neutral entity, rather separate from its social and cultural dimensions, as exemplified by Canter (1991) in environmental evaluation studies. Again, much EBS research has taken a singular view of people, disregarding their purposes, goals, and schemas. Both approaches are incomplete: people are equipped with highly complex cognitive mechanisms to act within/upon environments according to their purposes and goals. Environments contain structures and cues (e.g., Lynch, 1960; Barker, 1968; Hillier and Hanson, 1984) that interact with active, purposeful individuals (e.g., Snodgrass et al., 1988; Ward et al., 1988; Canter, 1991). People possess mental representations of places called schemas that they recall (and apply) at any appropriate time. Thus, as was exemplified in the restaurant example, place schemas contain information about physical (sensory, spatial), social and organizational (rules of place, type, order and appropriateness of activities, etc.), purposive and affective qualities of places. Therefore, in general, people equipped with the appropriate schemas immediately recognize from the cues provided (Rapoport, 1990a), the nature of the place and their role/position within it. Purpose carries a vital role in our shared social constructions of reality. People in the restaurant example, do not just happen to be there. They want to eat, socialize, so they plan accordingly, recognize the place, and enter. Once there, they know their role, what is expected and appropriate, and try to achieve their purposes, while meeting the expectations.

These mechanisms (schemas) that normally work so naturally may be noticed by the participants of places only when the amazing does not happen, when people do not know and can not guess how to behave in places. This happens when the rule systems of places and people conflict. One study (Küller, 1988, 1991) described in detail below is an example in which older adults could not function properly in an institutional environment probably because their schemas (including their related affective components) were incompatible with their new physical and social environment. Another example is people in places in which they 'do not belong', such as when they are faced with a foreign culture or social group that has very different rules and practices (e.g., Hall, 1966; also see Rapoport, 1990a). The existence of such social mechanisms has been demonstrated by 'breaching' studies in which purposive disturbances involving individuals acting differently from the expected were set up to uncover a person's taken for granted world (Garfinkel, 1967). These studies involve exercises in which the researchers have certain people act against the social norms (such as standing 'too' close, staring, etc.) to see the reaction of the 'regulars'. 
To comprehend how we get to understand places, one needs to consider all the elements and attributes that create places, and investigate how they relate to each other. Below is an attempt to understand what a place consists of, how it is created, and how we start conceptualizing such a place.

\section{THE CONCEPT OF PLACE}

A place, created by the integration of people, physical environment and program (Weisman, 1998, 2001) is a socially constructed, purposive, and meaningful environment. Here, the program includes elements of place experience, as well as, functions and rules of place. Thus, place is the physical environment given purpose and meaning by people. It brings together, in a complementary way, perception, cognition, affect, behaviour and meaning (referred to as modalities of place experience by Weisman, 1998, 2001), and the experiential nature of physical environments that include concepts such as privacy, crowding, legibility, accessibility, and so forth (referred to as 'attributes of place experience' by Weisman, 1998, 2001).

Although place is a frequently used concept in EBS and related fields, it is usually not well defined. In fact, according to Rapoport (1994), its definitions are illogical, its dimensions or attributes are not explicitly articulated, and it is often used in different and inconsistent ways, leading Rapoport (1994) to disregard the term altogether, arguing for the use of the non-value-laden term, 'setting' instead. I agree with Rapoport's (1994) and Canter's (1997) criticisms of the value-laden usage of the term place (i.e., place as 'liked setting', ' placelessness', 'non-place', 'placemaking', etc.; e.g., Relph, 1976), that sees it as a quality of a location. However, I believe that if the above criticisms are met, the concept of place, as considered here, is a central one for EBS, which can form the bridge between some of the currently separate viewpoints within the field (Groat 1984; Weisman, Chaudhury and Moore, 2000).

Canter defined place initially as "...units of experience within which activities and physical form are amalgamated", $(1997,1)$, and later, as "...a technical term for describing the system of experience that incorporates the personal, social and culturally significant aspects of situated activities" $(1997,117)$. The second dictionary definition of place is "a building or locality used for a special purpose" (Merriam-Webster on-line, 2009). Whereas Canter emphasizes (place) experience in defining place, the dictionary definition puts forward the physical and purposive nature of places. Of course, both the purposive and experiential nature of places are among the reasons we have a shared understanding of an integrative place concept, which makes co-action possible.

\section{A REVIEW OF RELATED RESEARCH ON PLACE AND PLACE EXPERIENCE}

Canter (1991) states that EBS is historically divided into three groups or fields: the cognitive group, the behaviourist group, and those that deal with assessment of environments, namely, the evaluative group. He argues that an integration of these groups, together with their way of studying our interactions with the environment may be very useful for EBS. Thus, he proposes perception/cognition, action and evaluation as components of place experience that needs to be studied for an integrative understanding 
of places. A brief review of the related research considering these components is given below.

It has been shown that people know where they are geographically in places by the help of previously acquired spatial or cognitive maps, and that this information is mostly agreed upon within groups and cultures (e.g., Lynch, 1960; Nasar, 1998). Barker (1968), who is more oriented toward the action component of place experience, studied how places operate in the form of behaviour settings. Barker views behaviour settings as smallscale social systems, with people and objects, as their components. These components act in an orderly system to carry out the settings' functions within their temporal and spatial boundaries (Wicker, 1987). People know from experience that they are supposed to act according to a specific predetermined schema (i.e., rules of place) in different settings. Barker (1968) calls this the "program of the setting".

People know the expectations or rules regarding the activities within specific environments because they are parts of the program of the setting. The fit between people's actions and features of physical objects of the setting is called environment-behaviour "synomorphy". In line with this argument, as discussed further in the next paragraph, Rapoport (1990a) argues that environments can work as mnemonics, helping us shape our behaviour according to the environment by using the cues embedded in it.

Barker sees the "operation" of places as similar to the operation of machinery, so he does not pay much attention to the people "component" of his system. Either he does not acknowledge or he undermines the active, purposive and emotional nature of people. In addition, according to Canter (1985), in his later studies in Oskaloosa, he did not even indicate the physical properties of the behaviour settings in which actions took place. Barker adopted an absolute view of behaviour settings - he did not consider them as dynamic entities that change with temporal and societal conditions. One of his followers, Wicker (1987) later brought forth the idea that behaviour settings could evolve and dissolve in time depending on their context. Rapoport has later developed the working of the "setting" based on research from Germany (Kaminski, 1987; Kruse, 1988; both cited in Rapoport, 1990a).

In a similar vein, Rapoport also suggests a general conceptualization of the same process. Covering all three components (i.e., perception/ cognition, action and evaluation), he conceptualizes the environment in "two very general ways that are complementary" (1997, p. 415). These are (a) "the organization of space, time, meaning and communication, which leads to" (b) "systems of settings / cultural landscapes made up of fixed, semifixed and nonfixed features, linked to behaviours via systems of activities (including their latent aspects), and communicated by cues" (1997, 415).

Rapoport's (1990a) low-level meanings are especially relevant for the purposes of this paper:

\footnotetext{
"Low-level' everyday and instrumental meanings: mnemonic cues for identifying uses for which settings are intended and hence the social situations, expected behaviour, and the like; privacy, accessibility; penetration gradients; seating arrangements; movement and way-finding; and other information which enables users to behave and act appropriately and predictably, making co-action possible" (221).
}

Rapoport refers above to both attributes (i.e., privacy, accessibility), and physical objects / properties (i.e., seating arrangements). He (1988, 
1990a) argues that unlike the high-level meanings, which refer to those related to cosmologies, cultural schemas, and the like, and middle-level meanings, which refer to identity and status, low-level meanings are the indispensable ones that all members of a society need to be well aware of, to fit in, because they "show" people how to act in a setting. The cues to these meanings must be present in the physical environment, for the setting to "work", through the interaction of the setting and related schemas; mnemonics are present in environments, and people "read" them. This view is similar to Barker's (1968) behaviour settings, in which everybody knows the program, and physical environment and people form a system that "works" (or does not work and hence, ceases to exist).

Meaning, whether it is instrumental or latent, is central to the existence of places. Instrumental or manifest meanings are those that are related to the purpose of the place. According to Rapoport (1988, 1990a), latent meanings are connected to places by association, and they can be more significant than the manifest ones. For example, although the manifest function of restaurants may be dining, they may more importantly serve purposes of socialization, dating or even demonstrating status. Other examples include studies which show that people can make judgments about the personal characteristics of occupants of houses by looking at drawings or photographs of house façades (Cherulnik and Souders, 1984; Cherulnik and Wilderman, 1986; Nasar, 1989); and one that shows people can make judgments about other people's personality traits and occupational statuses from their photographs taken in different residential settings (Cherulnik and Bayless, 1986). Another study by Duncan, Lindsey and Buchan (1985, cited in Rapoport, 1990a) found that furnishings, decorations, landscaping, and outdoor objects communicated meaning at a very high level of agreement (59 to $86 \%$, depending on cues and location).

People infer both affective responses and associational meanings from environments (Rapoport, 1977). From recent EBS research, a perception/ cognition oriented researcher, Nasar (1998) lists the following inferences people make from environmental cues:

"prestige, social position, class, or status, personality, use, identity, friendliness, neighborliness and homogeneity of neighbors, suitability to a campus and livability, safety, privacy, territoriality, and criminalizability (for potential burglars). These meanings may influence the emotional response and behaviours in relation to an area, and they may play an important role in the evaluative image" (27-8; see Nasar, 1998, for the related references).

Hence, we see that EBS literature supports Rapoport's (1988, 1990a) assertion that latent (associational) meanings can be more important than the manifest ones.

\section{VISUAL ASPECTS OF PLACE SCHEMAS}

The reason people can pick up meanings from environments with such apparent ease has to do with our schemas. In this regard, Purcell (e.g., Peron et al., 1998) studied the visual aspects of people's place schemas. He examined visual preferences, expectations, and building identity / image using the concept of prototype, for a more integrative nature of place experience. Purcell examines the "goodness of example" (similar to the concept of "exemplar" by Rosch, 1978) of building types, which are prototypical representations of images of buildings stored in schemas. His findings provide support for consensus within groups about schemas. For example, although designers and lay people seem to have different preferences for house façades, their preferences are similar within their 
groups (e.g., Groat, 1982; Devlin and Nasar, 1989; Purcell, 1995; İmamoğlu, 2000).

The way we use our schemas to (visually) infer meaning has also been mentioned by Canter (1985):

"What all these studies (Groat, 1982; Krampen, 1979) reveal is that there is an organised, structured relationship between what buildings look like and the types of activities and institutions that those buildings are expected to house. In effect, these studies show that the physical form of a building can be used to indicate the patterns of activity anticipated within them" (178).

Also, in relation to the restaurant example noted above, Cherulnik (1991) found "a strong consensus" among university students whose schemas about restaurants were examined $(1991,167)$. This indicates a high degree of legibility of places by way of congruence across modalities of place experience (i.e., perception, cognition, affect, behaviour and meaning), which supports Rapoport's and others' arguments above.

\section{MOTIVES AND ROLES REGARDING PLACE SCHEMAS}

Other research in EBS focuses on people's motives and purposes, and how they relate to actions in places (e.g., Ward and Russell, 1981; Canter, 1985), and thus, the creation of places. Those studies that focus on both cognition and action show that people do not come into environments as clueless as mannequins, but with motives, purposes, intentions, roles, and schemas.

Genereux et al. (1995) explore the idea that behaviour may be an important part of the meaning people attribute to physical environments, and reach supporting conclusions. According to their study, people clearly distinguish places depending on the related behaviour, and their behavioural representation of places affect their overall understanding (or cognition) of places. They also argue that people's judgments about places differ depending on the possible behaviours that may occur there, the suitability of the places for those behaviours, their reasons for going there and what they do there. According to this view, people may evaluate places according to the specific behaviours that may take place there, and they might prefer places offering more behaviour possibilities (Genereux et al., 1995). Ward et al. (1988) predicted that planning of activities influences the interaction between the person and the place. They found that planning affects both the affective appraisal and the memory of the place; a finding that supports the integrative nature of place experience. Thus, given that behaviours are place-specific, certain places may be evaluated not only by their physical qualities, but also by the possible behaviours that can take place there, as well as the person's behaviour plans.

Canter (1985) states that people form an understanding of the primary purposes of places by experiencing the consistent patterns of space-use that reflect meanings for them. He argues that "role" is an important factor that determines our purposes in places. People create their personal purposes through a process of interaction with the perceived goals of the organization and social system to which they belong. Canter (1985) argues that:

"satisfaction will be a function of the extent to which a person feels able to achieve his or her goals in that place, which is related to environmental fit, or congruence. It follows, therefore, that people performing different roles in any given place will have different patterns of satisfaction with that place" (182). 


\section{A REVIEW OF RELATED RESEARCH ON PLACE SCHEMAS}

People use their schemas to make sense of the overabundant information embedded within places. As has been briefly discussed, schemas are codified experiences that create people's awareness of the surrounding environmental information. They help us deal with large amounts of perceptual information (e.g., physical, spatial, social and organizational) that we face in places - by creating generalized chunks that can continuously be modified when introduced to novel information. Thus, schemas provide structure to our perception/ cognition, and help create our place experience.

The concept of schema is an integral part of the interaction between humans and environments. As a theoretical construct having its origins in the "cognitive" tradition of psychology, it appeared long before the "cognitive revolution" of the 1960s (initiated by Tolman and later developed by Neisser; see Neisser, 1976). In 1932, Bartlett (1954) demonstrated that people trying to reconstruct a picture depend on certain internal representations as reference. These representations not only allow the "new" picture to be developed, but are also responsible for any distortions from the memories of the original. Bartlett saw such representations, referred to as schemas, as residues of our past experiences that allow us to make instant sense of ambiguous environmental situations that we encounter in our lives. Schemas grow and develop as we make more and more sense of our environments.

According to Canter (1977), in 1956, Boulding, coming from a different tradition (economics), contributed to the concept of schema by studying people's "subjective knowledge" that make up their "image of the world". Boulding argued that the schemas people use come together to make up a coherent whole, which he called "the image". Boulding's view suggested that schemas may not be separate entities, but are organized into a whole that not only influences people's view of events, but their behaviour as well. Although Boulding describes the physical environment, his use of "image" is not solely about the physical environment. This integration would be made a few years later, as explained below.

With the development of computers, a different field of research in the 1970s and 1980s helped develop Bartlett's concept of schema. Marvin Minsky (1975) introduced frames, an essentially synonymous concept to schemas that was used as a construct both in psychology and in the emerging field of artificial intelligence. Other such research included the concept of scripts (i.e., event schemas; Schank and Abelson, 1977) that investigated ways of modeling knowledge about human interactions.

Brewer and Treyens (1981) connected schemas to physical environments (i.e., place schema) in a study that shows people's memory for places is affected by expectations. They asked the respondents to remember items and their locations from an office setting that included both items related to offices and others that did not. The results of the study indicated that people recalled objects consistent with their expectations (and objects with noticeable features), as well as some that strongly contrasted with their expectations about an office. Respondents even shifted the locations of objects from their actual locations to the ones that would be expected in an office. Although this study is one of the earliest to specifically connect schemas to information in the physical environment, this connection was made much earlier, as described below. 
Around the time when Boulding was working on schemas, one of Bartlett's students, Terence Lee (1954, cited in Canter, 1977; Lee, 1970) was the first to study schemas about socio-physical environments. Lee was interested in the formation of the neighborhood concept in people's minds. He asked the respondents whether they had a "neighborhood", and after getting a positive response, asked them to draw its borders on a city map that had their house marked at the center of it. Lee (1970) states that

"Seventy-five percent of the sample had a sufficiently salient mental organization of the space and people around about [sic] them to communicate a decided impression of it to an unexpected caller. Of the remaining 25 percent, some would clearly have been able to do so if they had been resident longer" (354).

This shows that a substantial majority of people had very specific notions of the borders of their neighborhoods. Lee (1970) further argues:

"Hitherto neighbourhood has been considered as an individual phenomenon, but there is obviously a sense in which it has collective expression. Although there is diversity there is also uniformity and the relations between overlapping individual neighbourhoods need to be conceptualized and measured" (365).

These line drawings that Lee described as representations of socio-spatial schemas suggest the existence of people's shared internal representations about their environments. The significance of Lee's study is that it shows that schemas exist, not only individually, but also, at the level of the society, as consensual schemas, as argued above. Lee states:

“... Repeated transaction with people and places in the urban environment leads, by a process of differentiation, to the separation of an organized sociospatial whole. ... People, buildings and space are articulated into a figure which is well-defined and stand out from the ground, which is vague and formless. The figure has boundaries and the space within is continuous; it appears 'different' from the remainder; it has familiarity and 'meaning.' It is a representation in which the objects and people have affective as well as locational coding" (1970, 354).

Following Lee's socio-spatial schemas, Kevin Lynch (1960) used the term, image, previously used by Boulding, more directly in reference to places, and he examined schemas associated with cities, in his influential book The Image of the City. Lynch interviewed 60 people in three U.S. cities, and asked the respondents to draw sketch maps of their images of the city they lived in. He also asked for descriptions of their trips in the city and of the parts of the city they remembered especially well. These sketch maps, derived from verbal interviews, demonstrate that people develop structured cognitive maps about their spatial environments, and the fact that most of the maps overlap indicates that people have a consensus about a large extent of their environmental schemas, providing strong support to the consensual nature of place schemas and experiences.

Lynch (1960), referred to a process of producing structure from the environment:

"We find, in comparing these three cities (if we can find anything in such small samplings) that, as might be expected, people adjust to their surroundings and extract structure and identity out of the material at hand" (43).

In consistency with Lynch's ideas, Neisser (1976) defines a schema as a "connecting link between perception and the higher mental processes". He states that a schema is internal to the perceiver, and is modified by new 
information coming via experience. When we walk through environments, we perceive (and cognize) them with the help of, or through the filters of our schemas. At this point, we spot any discrepancies from the existing schemas either for an update (confirming or modifying), or to disregard them if found irrelevant. Thus, not only do our schemas change the way we perceive environments, but also, the environments modify our schemas.

Fiske and Taylor (1984) note that "The most fundamental principle suggested by schema research is that people simplify reality; they do so in part by interpreting specific instances in light of the general case" (141). According to Neisser (1976), cognitive psychologists used to assume a mental activity flow from the specific to the general, in successive stages. However, we do not determine all the features of a new environment first, bring them together and then give them meaning; we can make sense of a new environment almost instantly. Schemas and cognitive maps suggest that such information may be embedded rather than successive (Neisser, 1976). Thus, we are probably using bundled information that we recall from memory by the help of certain cues in the environment. In a similar vein, Lynch (1960) notes, "The image itself was not a precise, miniaturized model of reality, reduced in scale and consistently abstracted. As a purposive simplification, it was made by reducing, eliminating, or even adding elements to reality, by fusion and distortion by relating and structuring the parts. It was sufficient, perhaps better, for its purpose if rearranged, distorted, 'illogical.'"' (87; my italics)

\section{PLACE SCHEMAS}

In view of the general definition of schema as "a cognitive structure that represents organized knowledge about a given concept or type of stimulus" and "contains both the attributes and the relationships among the attributes" (Fiske and Taylor, 1984, 140), place schemas can be said to represent organized knowledge about places and place experiences (e.g., Brewer and Treyens, 1981).

Ultimately, we need to develop a shared understanding of certain concepts to be able to achieve our purposes in life. Likewise, place schemas may be likened to complex miniature models of places, but ones molded and distorted to be congruent with our purposes and needs - as suggested in Lynch's description of the image above. Place schemas, like maps, limit the potentially enormous quantities of place information to manageable proportions by including only that which is most relevant, and by abstraction; like maps, we carry these miniature models for guidance in complex environments.

We build schemas through our interaction with the environment. Our experience is organized and represented in schemas at various levels ranging from discrete features to general categories (Mandler, 1982). To make use of our schemas, we first need to identify objects and group them as members of a category. This process of categorization helps us make sense of a complex world (Rosch, 1978). We use some members of categories that we think are representative of those categories as reference points. These abstract representative members are called "prototypes", and we use them to figure out if a new object belongs to a category by comparing it to its prototype (Rosch, 1978; Augoustinos and Walker, 1995). Note that a prototype does not carry all the features of that category, just the most common ones. For example, a prototypical sports car might be a red Ferrari, but one can easily recognize another sports car by comparing 
it to this prototype, even when the color and the make do not match (Fiske and Taylor, 1991). Similarly, place schemas carry physical and spatial information about place types, in the form of prototypes; these "best example" categories carry the most common features and elements of the place types they represent (Rosch, 1978; Mandler, 1984; Purcell, 1987). As briefly mentioned above, place schemas also carry information regarding scripts - or event schemas (Schank and Abelson, 1977; Fiske and Taylor, 1991) - belonging to that place type. Such scripts include information on social patterns, activities, expectations and order of events. Affective associations always accompany this information (Snodgrass et al., 1988; Ward et al., 1988; Genereux et al., 1995).

As has been mentioned, different types of meaning are embedded in environments, and people can read into environments by the use of cues (provided that they are culturally appropriate and strong enough; Rapoport, 1990a). Cues help people define and understand environments in specific and shared ways. They help stimulate people's schemas so that, environments are not seen as "mere environments," but as meaningful "places". In places, people "know" what is and is not appropriate, and can then act according to these "rules". Thus, the congruence of the "rules" of place (Canter, 1991) and people's actions brings about and prolongs the operation of places, and helps places continue to evolve through time. Similarly, Stokols and Shumaker (1981) define environmental congruence as the degree to which the environment enables occupants to meet their needs and attain their "valued goals" (480). Stokols (1981) sees this level of congruence between functions of place (or "setting", as referred to by Stokols) and group goals as essential to the perception of environmental quality.

The study described below may be significant in exemplifying an integrated contextual approach to environmental design, and include the concepts of place and schema to improve the congruence of the environment and its users.

\section{RECENT RESEARCH ON OLDER ADULTS REGARDING PLACE SCHEMAS}

In long-term care environments, there is usually monotony and an absence of social contacts for patients. In the long run, patients cannot get the necessary level of stimulation and become under-stimulated. This causes intellectual and emotional changes that help the patient to adapt to this low-level stimulation. Although patients become more compliant, "acute states of confusion, depression or aggression are often observed in institutionalized patients, which suggests that the adaptation is deceptive" (Küller, 1988, 216).

According to Sutinen (1976, cited in Küller, 1988), the physical designs of the acute and chronic disease departments of modern hospitals resemble each other in the way that they are designed for efficiency and rational planning with the goal of lower initial and running costs. Thus, the long-term patients have to share the same unfriendly "institutional" environments as acute treatment patients. One of the reasons for this might be that architects who are specialized in acute treatment designs also design the chronic care departments. Perhaps more important reasons are those that contribute to the negative labeling of the word "institutional", like routine, unimaginative thinking, and a demand for "rational" decisions 
based mainly on finances (Sutinen, 1976, cited in Küller, 1988), which create the homelike-institutional duality as hypothesized by Robinson and colleagues (Robinson et al., 1984; Robinson, 1988; also see Day, Carreon and Stump, 2000).

In such an institution, in Sweden, Küller and colleagues tried to create a more "homelike" environment for the cognitively impaired patients that would counteract the institutionalization process (Küller, 1988, 1991). They redecorated the dining room of a geriatric long-term hospital in such a way that it would be similar to the patients' home environments during the years that they were most active.

The layout, the furnishing, lighting levels, and color schemes were changed, personal clothing was used, food was served on china selected by patients themselves, and the meals were taken together with the staff. These changes were guided by conversations with the patients and expert opinion. To evaluate the intervention, the patients' behaviours were observed, they were given medical checks and clinical tests, and both patients and staff were interviewed. The results indicated that the patients felt happier, became socially more receptive, and increased their food intake (Küller, 1988). Those results are congruent with the more recent literature on environments for people with dementia, which shows that "residents in non-institutional settings are less aggressive, preserve better motor functions, require lower usage of tranquilizing drugs, and have less anxiety" (Day, Carreon and Stump, 2000, 407) compared with those in institutional settings, such as nursing homes and hospitals.

The above studies show that even small changes in the socio-physical environment can help its users have a more harmonious relationship with their environment. Such changes may counteract the feelings of incompatibility with the environment, provided that they are made in congruence with the understanding of an appropriate social context and the schemas of the residents. As mentioned previously, in Küller's study, the researchers furnished and decorated the dining room as a typical room would be at the time they were younger and active, thus probably making a connection with their schemas of "homelike" places. Here, the "institutional" hospital setting was changed into a more familiar, "homelike" "place" for both the patients and the staff, resulting in the initiation of different schemas, and hence different expectations and rules of place (also see Canter, 1991). This "transformed" place also carried with it the environmental cues with which patients were familiar, together with a different level of complexity that they were probably more used to, both of which probably supported the improvements. Finally, though the focus in the above study is on patients, I believe that the possible effects of the new environment on staff should also be emphasized. The new features of the physical environment had probably affected the assumptions the staff had made about the attributes of the patients as shown in the literature (Sadalla and Sheets, 1993, cited in Thompson et al.; 1996a; Thompson et al., 1996b), which probably influenced their approach to both the patients and the place.

Küller's study supports the views of researchers such as Barker and Rapoport, by showing that people do respond to relevant cues in their environment. Moreover, the fact that the people involved in the study were to some extent cognitively impaired, demonstrates that the environmental cues embedded in places are closely anchored in our cognitive mechanisms. The finding that even the cognitively impaired persons can 
pick up relevant cues from the physical environment in this study, and that the mentally retarded can distinguish homelike versus institutional features just as ordinary people do, in Thompson et al.'s study (1996b) may imply that this is a very basic and strong mechanism that probably has an evolutionary significance for the human organism (e.g., Kaplan and Kaplan, 1982, 1995). Human survival depended heavily on an accurate understanding of our environments, so organizing our environmental knowledge into schemas and linking these (spatial) schemas with the cues in the environment for quick retrieval was essential. Thus, it is very probable that the schemas that we have developed for today's complex environments may have originated from some basic requirements for survival in human history.

\section{TOWARDS AN UNDERSTANDING OF EMERGENCE AND EVOLUTION OF PLACES AND PLACE SCHEMAS}

One reason why places have been treated as neutral entities, and the concept of place experience has not appeared often in EBS literature is probably related to our lack of awareness of them. Just as we take for granted the established place types like schools and hospitals, we also know relatively little about newly emerging place types and the forces that shape them (Weisman, 1998). In the former, we have a good knowledge structure and well-developed schemas that have long become 'invisible' to us (Silverstein and Jacobson, 1978). In the latter, we have weak knowledge structures and are actively developing our schemas by incoming information as individuals, as well as modifying the place type as a society. Hence, schemas of newly emerging place types are also the ones that should be the most recognizable due to their incongruity. The fact that these newly emerging place types do not yet 'fit in', renders them very valuable for research on construction of place schemas and place experience. People have not yet developed the related schemas for the newly emerging place types, so they do not have a clear understanding of them. Because we have weak knowledge structures related to newly emerging place types, we are presently developing our schemas by the incoming information as individuals, and modifying the place type as groups and as a society. Schemas and images about new place types develop as we start to hear and learn about them, live in them, experience them. As such, newly emerging place types may provide many opportunities for research regarding the structure of place schemas and place experience.

Schemas guide perception and cognition (see Neisser, 1976). Like other schemas, place schemas are expected to guide the perception of ambiguous information and strengthen memory for schema-consistent information. People may make inferences from their schemas to fill in gaps where information is missing. Well-developed schemas are likely to be more abstract (i.e., they allow generalizations, beyond specific instances), complex (i.e., more attributes and more interconnections between them), organized (i.e., structured) and moderate (i.e., less extreme, like prototypes; Fiske and Taylor, 1984). Their organization, which is the number and structure of links among schematic contents, is richer and these schemas are also more resistant to change (Fiske and Taylor, 1991). Thus, one would think that the retrieval of the content information for, and evaluations of newly emerging place types, like assisted living would be slower because information about them would be less organized than those for well- 
established schemas, like homes (İmamoğlu, 2002, 2007; İmamoğlu and İmamoğlu, 2006).

\section{A MODEL PROPOSED TO CONCEPTUALIZE THE EMERGENCE AND EVOLUTION OF PLACE TYPES}

Accordingly, following the systemic view of place in EBS literature (e.g., Markus, 1972; Weisman, 1998), I proposed a model to examine the emergence of new place types and how they relate to place schemas through an interactive perspective, as shown in Figure 1 (İmamoğlu, 2002, 2007). According to the model, the human system comprised of individuals, groups, and organizations (including institutions) are in continuous interaction with the physical system of settings (within which activities take place; see Rapoport, 1977) around goals (as indicated by the arrows in the figure). From this interaction, place patterns -a reliable and observable sample of activities interconnected with particular physical settings- that emerge and evolve through time are created. Consequently, a dynamic place identity is formed by way of the place patterns evolving through the negotiation process of the human system on the one hand, and the evolving physical features of the physical system on the other. Our place schemas use the cues in this system of evolving place identities to respond to the system and update themselves (as the system is continuously evolving, whether it represents a newly emerging place type, or an established one). I should note that the cone-shaped figure is purely representational (indicating the process of defining a place), and does not necessarily imply that a final place identity (or a definitive place schema) can ever be reached.

It is important to note that the proposed model recognizes the interactive process of a place system not only during its emergence, but suggests that this is an ever-evolving process. Therefore, it supports the understanding that place schemas need to be evolving, too, even though, in general, they tend to be relatively stable.

Using the theoretical framework of this model as a base, I examined place schemas of assisted living, as an example of a newly emerging place type, compared to the better established schemas regarding homes and institutions. Assisted living is a new place type that emerged from the problems of the nursing home. It has two desirable objectives with respect to the long-term care needs of older adults. The first one involves a flexibility of care that meets the needs of individuals with differing levels of disabilities. The second one is the creation of a more "homelike" environment that promotes such attributes as resident privacy, independence, social interaction and the like (Regnier, 1994; Brummett, 1997; Schwarz, 1999).

As expected, my research suggested that the assisted living schema is directly linked to its parent place types of homes and nursing homes (being positively associated with home schema, and negatively associated with nursing home schema). Thus, a new place schema seems to develop in association with the already existing schemas of related places. Furthermore, in congruence with the schema literature, affect and familiarity seem to play important roles in the conception of places (İmamoğlu, 2002; İmamoğlu and İmamoğlu, 2006). For instance, in line with the mere exposure hypothesis (Zajonc, 1968), familiarity with the neutral or somewhat positively evaluated assisted living facilities seems to lead to more positive evaluations, whereas increased familiarity with 
Figure 1. A proposed interactive process model of a newly emerging place system (İmamoğlu, 2002).

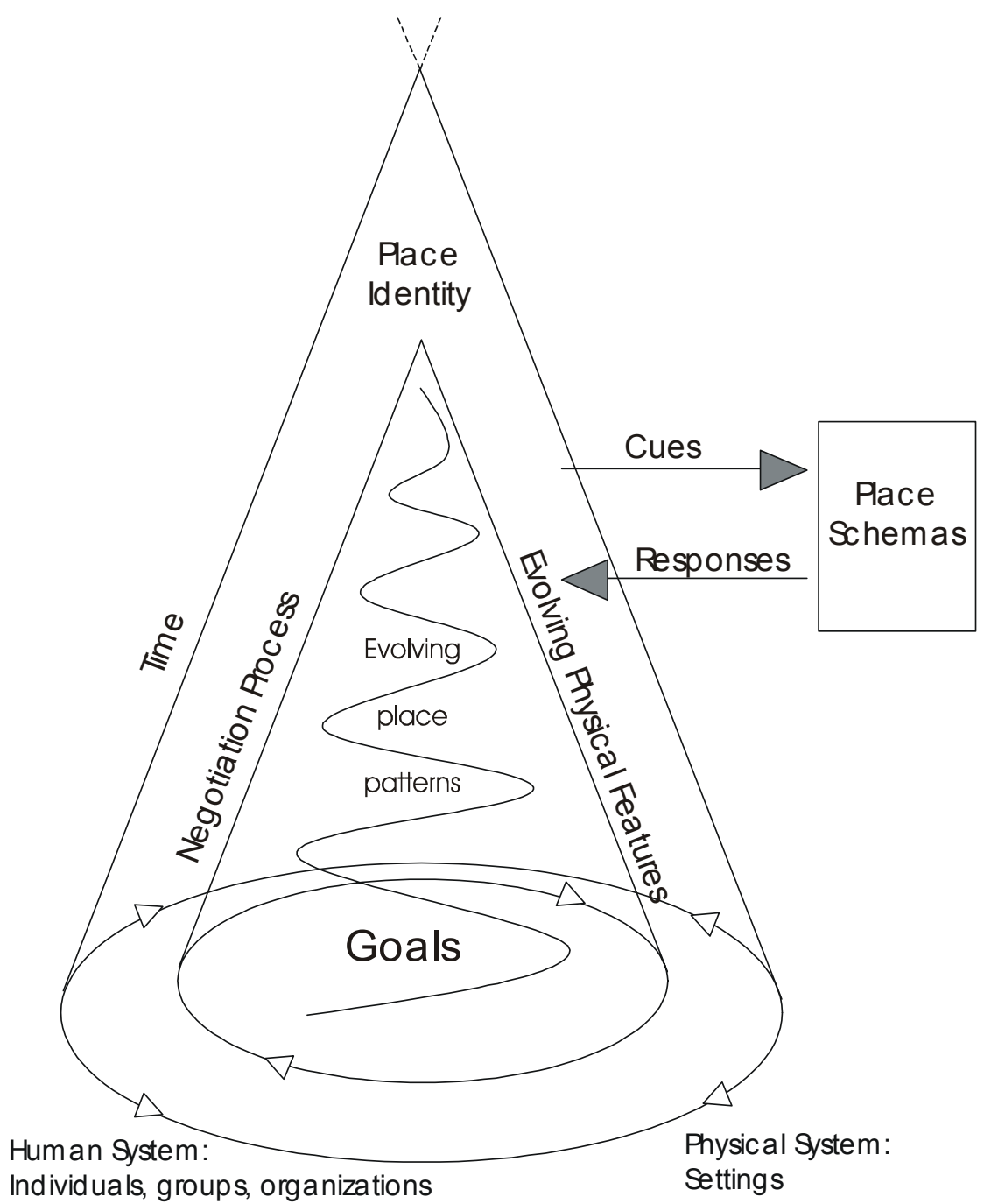

nursing homes seems to enhance the already existing negative evaluations (İmamoğlu and İmamoğlu, 2006).

Also, my research supported the proposition that the goals of older adults, their families, and representations of related organizations (e.g., government regulations and advertisements of assisted living facilities) interact with the function and form of the physical setting, paving the way for new (more homelike) place patterns to emerge. In this regard, my findings suggested that the function-related meaning of a new place type seems to emerge before form-related (visual) expectations; but over time, or in well-developed schemas, the two may become closely interrelated, such that the form may become the label for the meaning concerned (İmamoğlu, $2002,2007)$. For instance, although there appeared to be a consensus about the function-related aspects of assisted living, it was not yet associated with a particular physical form (İmamoğlu, 2002, 2007). Similarly, it is conceivable that the meanings of well-developed place identities (such as the mosque, church or synagogue) first emerged in terms of a particular function (e.g., as places of gathering to pray), but in time, particular forms of buildings emerged, which in fact became labels (or visual representations) for those particular meanings. As noted, this process 
is not finite, but is an evolving one. My research also provided general support for the consensual nature of place schemas: The respondents seemed to agree on certain attributes of assisted living, which seemed to be cognitively represented in a richly interconnected web-like form, as well as those of homes and nursing homes (İmamoğlu, 2002, 2007).

\section{CONCLUSION}

In this paper, as well as emphasizing the cognitive structure of an integrative concept of place, I tried to emphasize the significance of the attributes of places to have a better understanding of those cognitive structures, namely, place schemas. I believe that our place schemas mainly contain knowledge regarding place experience, a concept that lies at the core of what EBS aims to understand.

In spite of the wide variability among people and environments and the relativity of environmental quality, there are common understandings among people about places and place types within cultures and especially within groups. The fact that respondents in Lee's (1970) and Lynch's (1960) studies and other similar research (e.g., Nasar, 1998) give similar responses, as reflected in the resulting maps, indicate that schemas about places are mostly consensual. Rapoport notes (1990a, 1990b, 1994) that the subjective experience of users is highly relevant for understanding environment-behaviour relations, provided that it can be generalized to groups. Such a consensual definition emphasizing the systemic qualities of the environment can be very beneficial (Groat, 1984; Weisman, Chaudhury and Moore, 2000; Weisman and Moore, 2003), if not essential for EBS. The research on places and proposed models of place in EBS literature could be beneficial in our understanding of the consensual nature of place schemas.

Hence, in this paper, I tried to give an overview of the literature on schemas, and to argue that place schema is a useful concept to understand how people comprehend places, and encode their place experiences. I explored the related literature to demonstrate the idea that place schema can be utilized to improve people's well-being and satisfaction with places that better serve their needs and expectations, as exemplified by the recent research on older adults. Finally, I proposed an interactive process model of a newly emerging place system and referred to some supportive evidence from my research about assisted living facilities, representing a newly emerging place type as compared to the well-established place types of homes and institutional living.

A better understanding of places and how they operate may enable us to ask acute research questions and conduct more contextual research than has been done in the past. The concepts of place, place experience and place schemas may help provide a theoretical structure to the questions environment-behaviour researchers ask, such as, 'How do people classify places in their minds?'; 'How do people interpret and attach meaning to elements of specific places and know how to act in them? How do these meanings affect their evaluations?'; 'What are the shared individual (intersubjective) opinions and generic knowledge structures about certain places, and how are these environments different from others?'; 'How does the way people associate certain feelings and experiences with certain places change the way those environments are perceived and cognized?', and so on. Future research addressing these and similar questions can improve our understanding of place experience, and can lead the way to more productive research and better functioning living environments. 


\section{BIBLIOGRAPHY}

AUGOUSTINOS, M., and WALKER, I. (1995) Social Cognition: An Integrated Introduction, Sage, London.

BARKER, R. G. (1968) Ecological Psychology, Stanford University Press, Stanford, CA.

BARTLETT, F. C. (1954) Remembering (First published in 1932), Cambridge University, Cambridge, England.

BREWER, W. F., and TREYENS, J. C. (1981) Role of Schemata in Memory for Places, Cognitive Psychology, 13; 207-30.

BRUMMETT, W. (1997) The Essence of Home: Design Solutions for Assisted Living Housing, Van Nostrand Reinhold, New York.

CANTER (1977) The Psychology of Place, The Architectural Press Ltd, London.

CANTER, D. (1985) Intention, Meaning, and Structure: Social Action in Its Physical Context, Discovery Strategies in the Psychology of Action, eds. G. P. Ginsburg, M. Brenner, and M. von Cranach, Academy, London; 171-86.

CANTER, D. (1991) Understanding, Assessing, and Acting in Places: Is an Integrative Framework Possible? Environment, Cognition, and Action, eds. T. Garling, and G. W. Evans Oxford University, New York; 191209.

CANTER, D. (1997) The Facets of Place, Advances in Environment, Behaviour, and Design, 4, eds. G.T. Moore and R.W. Marans, Plenum, New York; $109-47$.

CHERULNIK, P. D. (1991) Reading Restaurant Façades: Environmental Inference in Finding the Right Place to Eat, Environment and Behaviour, 23 (2) 150-70.

CHERULNIK, P. D., and BAYLESS, J. K. (1986) Person Perception in Environmental Context: The Influence of Residential Settings on Impressions of Their Occupants, The Journal of Social Psychology, 126(5) 667-73.

CHERULNIK, P. D., and SOUDERS, S. B. (1984) The Social Contents of Place Schemata: People are Judged by the Places Where They Live and Work, Population and Environment, 7 (4) 211-33.

CHERULNIK, P. D., and WILDERMAN, S. K. (1986) Symbols of Status in Urban Neighborhoods: Contemporary Perceptions of NineteenthCentury Boston, Environment and Behaviour, 18 (5) 604-22.

DAY, K., CARREON D., and STUMP C. (2000) The Therapeutic Design of Environments for People with Dementia: A Review of the Empirical Research, Gerontologist, 40 (4) 397-416.

DEVLIN, K., and NASAR, J. K. (1989) The Beauty and the Beast: Some Preliminary Comparisons of "High" versus "Popular" Residential Architecture and Public versus Architect Judgments, Journal of Environmental Psychology, 9; 333-44.

FISKE, S. T., and TAYLOR, S. E. (1984) Social Cognition, Random House, New York. 
FISKE, S. T., and TAYLOR, S. E. (1991). Social Cognition (2nd ed.), McGrawHill, New York.

GARFINKEL, H. (1967) Ethnomethodology, Polity, Cambridge.

GEBOY, L. D. (2001) The Place Personality Characteristics of Health Care Settings: Hospital, Medical Clinic and Nursing Home, Presentation at the 32nd Annual Meeting of the Environmental Design Research Association, Edinburgh, Scotland.

GENEREUX, R.L., WARD, L.M., and RUSSELL, J.A. (1995) The Behavioural Component in the Meaning of Places, Readings in Environmental Psychology: Giving Places Meaning, ed. L. Groat, Academic, London; 43-55.

GROAT, L. (1982) Meaning in Post-Modern Architecture: An Examination Using the Multiple-Sorting Task, Journal of Environmental Psychology, $2 ; 3-22$.

GROAT, L. N. (1984) Book Review of A. Perez-Gomez: Architecture and the Crisis of Modern Science, Journal of Environmental Psychology, 4; 183-87.

GUMP, P. V. (1987) School and Classroom Environment, Handbook of Environmental Psychology, v: 1, eds. I. Altman and D. Stokols, John Wiley, New York.

HALL, E. T. (1966) The Hidden Dimension, Doubleday and Company, New York.

HILLIER, B., and HANSON, J. (1984) The Social Logic of Space, Cambridge University Cambridge, England.

İMAMOĞLU, Ç. (2000) Complexity, Liking and Familiarity: Architecture and Non-Architecture Turkish Students' Assessments of Traditional and Modern House Facades, Journal of Environmental Psychology, 20 (1) 5-16.

İMAMOĞLU, Ç. (2002) Toward an Understanding of Place Schema: Societal and Individual-Level Representations of Assisted Living, unpublished Ph.D. dissertation, University of Wisconsin, Milwaukee.

İMAMOĞLU, Ç. (2007) Assisted Living as a New Place Schema: A Comparison with Homes and Nursing Homes, Environment and Behaviour, 39 (2) 246-68.

İMAMOĞLU, Ç. and İMAMOĞLU, E. O. (2006) Relationship between Familiarity, Attitudes and Preferences: Assisted Living Facilities as Compared to Nursing Homes, Social Indicators Research, 79 (2) 235-54.

KAPLAN, S. and KAPLAN, R. (1982) Cognition and Environment: Functioning in an Uncertain World, Praeger, New York.

KAPLAN, R., and KAPLAN, S. (1995) The Experience of Nature: A Psychological Perspective, Ulrich, Ann Arbor, MI.

KRAMPEN, M. (1979) Meaning in the Urban Environment, Pion, London.

KÜLLER, R. (1988) Housing for the Elderly in Sweden, Ethnoscapes, v:2, Environmental Policy, Assessment and Communication, eds. D. Canter, M. Krampen, and D. Stea, Athenaeum, Newcastle upon Tyne; 199224. 
KÜLLER, R. (1991) Familiar Design Helps Dementia Patients Cope, Design Intervention: Toward a More Humane Architecture, eds. W.F.E. Preiser, J.C. Vischer, E.T. White, Van Nostrand Reinhold, New York; 255-267.

LAWTON, M. P. (1980) Environment and Aging, Brooks/Cole, Belmont, CA.

LEE, T. (1970) Urban Neighbourhood as a Socio-Spatial Schema, Environmental Psychology: Man and His Physical Setting, eds. H. M. Proshansky, W. H. Ittelson and L. G. Rivlin, Holt, Rinehart and Winston, Inc., New York; 349-370.

LYNCH, K. (1960) The Image of the City, MIT, Cambridge, Mass.

MANDLER, G. (1982) The Structure of Value: Accounting for Taste, Affect And Cognition: The Seventeenth Annual Carnegie Symposium On Cognition, eds. M. S. Clark and S. T. Fiske, Lawrence Erlbaum Associates, New Jersey; 3-36.

MANDLER, G., (1984) Mind and Body: Psychology of Emotion and Stress, ed. W. W. Norton, New York.

Merriam-Webster's Collegiate Dictionary (On-line) (2009) Available: http:// www.m-w.com (accessed: July 2009).

MINSKY, M. (1975) A Framework for Representing Knowledge, The Psychology of Computer Vision, ed. P. H. Winston, McGraw-Hill, New York; 211-77.

NASAR, J. L. (1989) Symbolic meanings of house styles, Environment and Behaviour (21) 235-57.

NASAR, J. L. (1998) TheEvaluative Image of the City, Sage, Thousand Oaks.

NEISSER, U. (1976) Cognition and Reality, W. H. Freeman and Company, San Francisco.

PERON, E., PURCELL, A. T., STAATS, H., FALCHERO, S., and LAMB, R. J. (1998) Models of Preference for Outdoor Scenes: Some Experimental Evidence, Environment and Behaviour, 30, (3) 282-305.

PURCELL, A. T. (1987) Landscape Perception, Preference and Schema Discrepancy, Environment and Planning B: Planning and Design, 14; 67-92.

PURCELL, T. (1995) Experiencing American and Australian High- and Popular-Style Houses, Environment and Behaviour, 27; 771-801.

RAPOPORT, A. (1977) Human Aspects of Urban Form, Pergamon, Oxford.

RAPOPORT, A. (1988) Levels of Meaning in the Built Environment, CrossCultural Perspective in Nonverbal Communication, ed. by F. Poyatos, University of New Brunswick, Toronto; 317-36.

RAPOPORT, A. (1990a) The Meaning of the Built Environment (2nd ed.) University of Arizona, Tucson, Arizona.

RAPOPORT, A.(1990b) History and Precedent in Environmental Design, Plenum, New York.

RAPOPORT, A. (1994) A Critical Look at the Concept 'Place', National Geographic Journal of India, 40 (1-4) 31-45.

RAPOPORT, A. (1997) Theory in Environment-Behaviour Studies: Transcending Times, Settings, and Groups, Handbook of JapanUnited States Environment-Behaviour Research (Toward a Transactional 
Approach), eds. S. Wapner, J. Demick, T. Yamamoto, and T. Takahashi, Plenum, New York; 399-421.

REGNIER, V. (1994) Assisted Living Housing for the Elderly: Design Innovations from the United States and Europe, Van Nostrand Reinhold, New York.

RELPH, E. (1976) Place and Placelessness, Pion, London.

ROBINSON, J. W. (1988) Institution and Home: Linking Physical Characteristics to Perceived Qualities of Housing, Looking Back to the Future/Se Retourner Vers L'avenir: Proceedings of the $10^{\text {th }}$ Bienal [Sic] Conference of the International Association for the Study of People and Their Physical Surroundings (IAPS 10), v: 2, July 5-8, eds. H. van Hoogdalem, N. Prak, R. van der Voordt and H. van Wegen, Delft University, Delft, the Netherlands.

ROBINSON, J. W., THOMPSON, T., EMMONS, P., and GRAFF, M. (1984) Towards an Architectural Definition of Normalization: Design Principles for Housing Severely and Profoundly Mentally Retarded Adults, University of Minnesota, Department of Psycho-educational Studies, Minneapolis.

ROSCH, E. (1978) Principle of Categorization, Cognition and Categorization, eds. E. Rosch, B. B. Lloyd, Lawrence Erlbaum Associates, New Jersey; 27-48.

SCHANK, R. C., and ABELSON, R. P. (1977) Scripts, Plans, Goals, and Understanding, Erlbaum, Hillsdale, NJ.

SCHWARZ, B. (1999) Assisted Living: an Evolving Place Type, Aging, Autonomy, and Architecture: Advances in Assisted Living, eds. B. Schwarz and R. Brent, The Johns Hopkins University, Baltimore; 185-206.

SILVERSTEIN, M., and JACOBSON, M. (1978) Restructuring the Hidden Program: Toward an Architecture of Social Change, Facility Programming, ed. W. Preiser, Dowden, Hutchinson and Ross, Stroudsburg, PA.

SNODGRASS, J., RUSSELL, J.A., and WARD, L.M. (1988) Planning, Mood, and Place-Liking, Journal of Environmental Psychology (8) 209-22.

STOKOLS, D. (1981) Group X Place Transactions: Some Neglected Issues in Psychological Research on Settings, Toward a Psychology of Situations: An Interactional Perspective, ed. D. Magnusson, Lawrence Erlbaum Associates, New Jersey; 393-415.

STOKOLS, D., and SHUMAKER, S. A. (1981) People in Places: A Transactional View of Settings, Cognition, Social Behaviour, and the Environment, ed. J. H. Harvey, Lawrence Erlbaum Associates, New Jersey; 441-88.

THOMPSON, T., ROBINSON, J. and DIETRICH, M. (1996a) Interdependence of Architectural Features and Program Variables in Community Residences for People with Mental Retardation, American Journal on Mental Retardation, 101 (3) 315-27.

THOMPSON, T., ROBINSON, J., DIETRICH, M., FARRIS, M. and SINCLAIR, V. (1996b) Architectural Features and Perceptions of Community Residences for People with Mental Retardation. American Journal on Mental Retardation, 101 (3) 292-313. 
WARD, L.M. and RUSSELL, J.A., (1981) The Psychological Representation of Molar Physical Environments, Journal of Experimental Psychology; General, 110; 163-8.

WARD, L.M., SNODGRASS, J., CHEW, B. and RUSSELL, J.A. (1988) The Role of Plans in Cognitive and Affective Responses to Places, Journal of Environmental Psychology (8) 1-8.

WEISMAN, G. D. (1998) Toward a Model of Architectural Research and Design: Pragmatism, Place and Patterns, Presentation to the SubCommittee of Environment Behaviour Studies and Working Group of Person-Environment Model in the Architectural Institute of Japan, May 28.

WEISMAN, G. D. (2001) The Place of People in Architectural Design, Architectural Design Portable Handbook: A Guide To Excellent Practices, ed. A. Pressman, McGraw-Hill, New York; 158-70.

WEISMAN, G. D., and MOORE, K. D. (2003) Vision and Values: M. Powell Lawton and the Philosophical Foundations of Environment-Aging Studies, Journal of Housing for the Elderly, 17 (2) 23-37.

WEISMAN, G. D., CHAUDHURY, H. and MOORE, K. D. (2000) Theory and Practice of Place: Toward an Integrative Model, The Many Dimensions of Aging, eds. R. Rubenstein, M. Moss and M. Kleban, Springer, New York.

WICKER, A. W. (1987) Behaviour settings reconsidered: Temporal stages, resources, internal dynamics, context, Handbook of Environmental Psychology, 1, eds. D. Stokols and I. Altman, John Wiley and Sons, New York; 613-53.

ZAJONC, R. B. (1968) Attitudinal effects of mere exposure, Journal of Personality and Social Psychology Monograph Supplement, 9 (2) Pt. 2.

\section{'YER'İ ANLAMADA ŞEMA KAVRAMININ ROLÜ}

Mimarlık literatüründe 'yer' (place) kavramı, insanlarla fiziki çevrenin amaçlara uygun bir program çerçevesinde buluştuğu (Weisman, 1998, 2001), sosyal anlam içeren bir mekan olarak düşünülebilir. Bu tanımda program, belirli bir yer veya mekanla ilgili deneyimleri, işlev ve kuralları içerir. Yer, insanların belirli amaç ve anlam kazandırdığı bir fiziki çevre olarak sözkonusu mekanla ilgili (algı, biliş, duygu, davranış ve anlam gibi) deneyim araçlarının yanı sıra oradaki deneyimlerimizle ilgili olarak yaptığımız (mahremiyet, kalabalıklık, okunabilirlik, ulaşılabilirlik gibi) atıfları da bir araya getirir (Weisman, 1998, 2001).

İnsanlar yerleri, işleyişlerini ve buralarda edindikleri deneyimlerini 'şema' olarak adlandırılan bilişsel yapıları aracılığıyla temsil eder ve öğrenirler. Benzer şekilde, yer şemaları da ilgili yerlere dair her türlü bilginin (fiziksel, mekansal, sosyal ve kurumsal gibi) kodlanmasıyla oluşur ve çevreyi algılamamızda önemli bir rol oynar. Mevcut makalede yer şemalarının incelenmesinin ve anlaşılmasının insan-çevre ilişkileri araştırmaları ve ilgili uygulama projeleri için yararlı bir kavramsal çerçeve 
sunabileceği savunulmaktadır. Bu doğrultuda, öncelikle, yer olgusu ele alınmakta; literatürde sıklıkla kullanılan bu kavramın yeteri kadar iyi tanımlanmadığı vurgulanmakta ve değişik tanımları tartışılmaktadır. Yer deneyimi ile insanların yeri algılaması arasında önemli ölçüde örtüşmeler bulunduğuna dikkat çekildikten sonra ilgili literatür çerçevesinde insançevre ilişkilerinde yer şemalarının önemi vurgulanmakta ve yerlerin ortak (consensual) kavranışının mekan deneyimine olan etkisi ele alınmaktadır. Ardından, yaşlılar için tasarlanmış mekanlarla ilgili uygulamalı bir çalışma örneği sunulmaktadır. İsveç'te yapılmış olan sözkonusu çalışmada araştırmacılar (Küller, 1988, 1991) yaşlılara hizmet veren bir hastanenin yemek odasının tasarımını kullanıcılarının gençliklerinde alışık olduklarına benzer şekilde değiştirmiş; kullanıcıların çalışanlarla birlikte, ev ortamındaki gibi yemek yemelerini sağlamışlardır. Bulgular kullanıcıların bu değişikliğin ardından daha mutlu ve sosyal olduklarını göstermiştir. Anılan çalışma yaşadığımız yerlerin tasarımında yapılacak küçük değişikliklerin bile (örneğin yukarıdaki çalışmada 'kurum' şemasından uzaklaşıp 'ev' şemasına yaklaşıldığı gibi) kullanıcıları 'yer' ile daha uyumlu hale getirebileceğini göstermesi açısından önemlidir.

Makalenin ikinci kısmında ise mekan sisteminin oluşma ve gelişme sürecine ilişkin kavramsallaştırmayı özetleyen bir model önerilmektedir. Anılan modelde insan sistemi ile fiziki sistem arasında amaçlar çerçevesinde bir etkileşim olduğu varsayımından hareketle, bu etkileşimden yer örüntülerinin ve yer kimliğinin ortaya çıktığı ve zamanla evrimleştiği; ilgili yer şemalarının da bu evrimleşen sisteme ilişkin algılanan ipuçlarıyla oluşup gelişebileceği önerilmektedir. Ardından, yazarın yaşlılar için mekanlar konusunda önerdiği model çerçevesinde elde ettiği bazı görgül araştırma bulgularından örneklere değinilmekte ve gelecekteki araştırmalar için önerilerde bulunulmaktadır. Sözkonusu bulgular özetle şöyledir: İnsanların destekli yaşam imkanlarına (assisted living facilities) ait yeni oluşmakta olan şemaları, gelişmiş ev ve huzurevi (nursing home) şemalarıyla doğrudan ilişkili olarak gelişmektedir. Yeni gelişmekte olan destekli yaşam imkanları şemalarının ev şemasıyla olumlu, huzurevi şemasıyla ise olumsuz bağlantı içinde olduğu bulunmuştur (İmamoğlu, 2002; İmamoğlu ve İmamoğlu, 2006). Sözkonusu bulgu, yeni gelişen yer şemalarının bunlarla ilişkili yerlerin varolan şemalarından türetildiğine veya onlarla kıyaslanarak geliştiğine işaret etmektedir. Anılan bulgular duyguların ve tanıdıklığın yer oluşumu/kavrayışında önemli etkileri olduğuna işaret etmektedir. Bunun yanısıra yazarın araştırmaları, yaşlıların, yakınlarının ve ilgili kurum ve kuruluşların (örneğin, devlet yönetmelikleri, destekli yaşam imkanları reklamları aracılı̆̆ıyla) birlikte çalışmasıyla sözkonusu yerlerin işlev ve biçimlerinin değişip gelişebileceğini ve yeni (daha 'ev' benzeri) yer örüntülerinin ortaya çıabileceğini göstermektedir (İmamoğlu, 2002, 2007).

Yazarın araştırmalarından çıkan diğer bir bulgu da, yeni oluşmakta olan yerler sözkonusu olduğunda, işlevle ilişkili anlamlandırma veya beklentilerin formla ilgili görsel beklentilerden önce oluştuğu; ancak gelişmiş yer şemalarında bu ikisinin birleşebildiği ve formun, yeri çağrıştırabildiği yönündedir. Diğer bir deyiş̧le, işlev formdan veya fiziki şekilden önce gelmektedir; ancak zamanla, sözkonusu yerle ilgili şemalar geliştikçe, belirli bir fiziki form o yerin sembolü haline gelebilir (örneğin, zihinlerde caminin belirli bir fiziki form ile temsil edilmesi). Ancak, daha zor olsa da zamanla sözkonusu sembolik temsiller de evrimleşebilme potansiyeli taşımaktadır. 
